\title{
EGFR inhibitor C225 increases the radiosensitivity of human lung squamous cancer cells
}

Yingdong Zhang ${ }^{1}$, Junjie Wang ${ }^{1 *}$, Feng Liu', Zhenyu You', Ruijie Yang ${ }^{1}$, Yong Zhao ${ }^{2}$

\begin{abstract}
Background: The purpose of the present study is to investigate the direct biological effects of the epidermal growth factor receptor (EGFR) inhibitor C225 on the radiosensitivity of human lung squamous cancer cell-H520. H520 cells were treated with different dosage of ${ }^{60} \mathrm{Co} \gamma$ ray irradiation $(1.953 \mathrm{~Gy} / \mathrm{min})$ in the presence or absence of C225. The cellular proliferation, colony forming capacity, apoptosis, the cell cycle distribution as well as caspase-3 were analyzed in vitro.

Results: We found that C225 treatment significantly increased radiosensitivity of $\mathrm{H}-520$ cells to irradiation, and led to cell cycle arrest in $G_{1}$ phase, whereas ${ }^{60} \mathrm{Co} \gamma$ ray irradiation mainly caused $G_{2}$ phase arrest. $\mathrm{H}-520$ cells thus displayed both the $G_{1}$ and $G_{2}$ phase arrest upon treatment with $C 225$ in combination with ${ }^{60} \mathrm{Co} \gamma$ ray irradiation. Moreover, C225 treatment significantly increased the apoptosis percentage of $\mathrm{H}-520$ cells $(13.91 \% \pm 1.88 \%)$ compared with the control group $(5.75 \% \pm 0.64 \%, \mathrm{P}<0.05)$.

Conclusion: In this regard, C225 treatment may make H-520 cells more sensitive to irradiation through the enhancement of caspase-3 mediated tumor cell apoptosis and cell cycle arrest.
\end{abstract}

\section{Introduction}

It is well known that many non-small cell lung cancer (NSCLC) cells over-express membrane surface epidermal growth factor receptor (EGFR) [1-7]. EGFR activation led to cell proliferation, angiogenesis and apoptosis inhibitory cytokines related phosphorylation and activation of cell signal pathway[8,9]. EGFR monoclonal antibody cetuximab (C225, Erbitux, Merck KGaA, Germany) inhibits tumor growth by directly impeding the EGFR ligands EGF and transforming growth factor- $\alpha$ (TGF- $\alpha$ ) combination of the above-mentioned cell block access [9-16]. In the in vitro studies, $\mathrm{C} 225$ combined with radiotherapy or chemotherapy inhibits the growth of head and neck squamous carcinoma cells dramatically. Furthermore, in the clinical treatment of head and neck squamous cell carcinoma [17,18], C225 combined with radiotherapy has also made a fantastic therapeutic effect $[14,15]$. At present, the clinical trials of $\mathrm{C} 225$ combined with radiotherapy and radiotherapy alone for patients with advanced NSCLC are under way[18], no clear conclusion has been

\footnotetext{
* Correspondence: doctorwangjunjie@yahoo.com.cn

'Department of Radiation Oncology, Cancer center, Peking University Third Hospital, Beijing, P.R. China 100191

Full list of author information is available at the end of the article
}

drawn. In this experiment H-520 cell proliferation, apoptosis and cell cycle distribution were detected after treating with $\mathrm{C} 225$ combined with radiotherapy.

\section{Materials and methods}

\section{Cell lines and culture}

The human non-small cell lung cancer cell line H-520 was purchased from Institute of Basic Medical Science, Peking Union Medical College (Beijing, China). H-520 cells were maintained in DMEM medium which was composed of $10 \%$ fetal calf serum, $1 \%$ penicillin and streptomycin (penicillin $100 \mathrm{U} / \mathrm{ml}$, streptomycin 100 $\mathrm{mg} / \mathrm{ml}$ ), and $1 \%$ glutamine. Cells were cultured in $37^{\circ} \mathrm{C}$ incubator with $5 \% \mathrm{CO}_{2}$.

\section{Determination of EGFR expression in $\mathrm{H}-520$ cells by flow cytometry}

Exponentially growing $\mathrm{H}-520$ cells were adjusted to $5 \times$ $10^{6} / \mathrm{ml}$ and incubated with mouse-against human EGFR antibody for $30 \mathrm{~min}$ at $4^{\circ} \mathrm{C}$. After washing with PBS twice, the cells were treated with FITC labeled goatanti-mouse IgG for $30 \mathrm{~min}$. The EGFR expression was detected by flow cytometry.
C Biomed Central

C 2010 Zhang et al; licensee BioMed Central Ltd. This is an Open Access article distributed under the terms of the Creative Commons Attribution License (http://creativecommons.org/licenses/by/2.0), which permits unrestricted use, distribution, and reproduction in any medium, provided the original work is properly cited. 


\section{Cell treatment with C225 and irradiation}

$\mathrm{H} 520$ cells were pre-cultured with $40 \mathrm{nM} \mathrm{C} 225$ for $12 \mathrm{~h}$, these cells and control cells then received a single dose of $\gamma$ ray irradiation from a ${ }^{60} \mathrm{Co}$ source (Peking University Health Science Center, China). The irradiation rate is $1.953 \mathrm{~Gy} / \mathrm{min}$.

\section{Cell growth analysis by methyl thiazolyl tetrazolium (MTT) assay}

Cell proliferation was determined by assessing the mitochondrial reduction of MTT. Cells were plated at $1 \times 10^{3}$ cells/well in 96-well plates containing $200 \mu \mathrm{l}$ growth medium and allowed to attach for $24 \mathrm{~h}$. The medium was removed. Blank control and C225 (0.008, 0.04, 0.2, 1, 5, 25,125 and $625 \mathrm{nM}$ ) groups were prepared and cells were incubated for $0,12,24,48,72$ and $120 \mathrm{~h}$. At harvest, the medium was removed from the appropriate wells, replaced with $50 \mu \mathrm{l}$ MTT solution $(2.5 \mathrm{mg} / \mathrm{ml})$, and incubated for $4 \mathrm{~h}$ at $37^{\circ} \mathrm{C}$. After incubation, the MTT solution was carefully aspirated and replaced with 150 ul DMSO. Cell growth was analyzed on a plate reader by using SoftMax program (Molecular Devices Corp., Menlo Park, CA). Experiments were performed in quadruplicate and repeated at least 3 times. Inhibition ratio $(\%)=(1-\mathrm{A} 190$ of testing group/A190 of the control group) $\times 100 \%$.

\section{Colony formation}

The cells in exponential growth were digested with trypsin into single cell suspension. Cells were seeded into $100 \mathrm{~mm}$ culture plates at various dilutions. Cells were distributed evenly in $10 \mathrm{ml}$ medium and maintained in incubator at $37^{\circ} \mathrm{C}$ for 14 days. Then the cells were fixed with methanol and stained with Gimsa. The colonies with more than 50 cells were counted. The plating efficiency (PE) was calculated as the formula: $\mathrm{PE}=$ number of colonies/number of seeded cells $\times 100 \%$. Results were shown as the mean value of quadruplicate samples in each dose.

\section{Dose-survival curve and sensitization enhancement ratio (SER)}

The H-520 cells were exposed to ${ }^{60} \mathrm{Co} \gamma$ ray irradiation, with the total dose of 100, 200, 400, 600, 800 and 1000 cGy. There are three samples in each dose group. After irradiation, cells were digested and seeded into $100 \mathrm{~mm}$ plates at different cell numbers. Then the cells were cultured in $35 \mathrm{~mm}$ plates for 14 days, and the formed colonies were counted. The survival fraction (SF) was calculated as the formula: SF = number of colonies/ number of seeded cells $\times$ PE. The dose-survival curve was fitted based on the one-hit multi-target formula $S F=1-\left(1-e^{-D / D_{0}}\right)^{N}$, with cell survival percentage as $\mathrm{Y}$-axis and absorbed dose as $\mathrm{X}$-axis, in which $\mathrm{D}$ was the absorbed dose, $\mathrm{D}_{0}$ was the mean lethal dose, and $\mathrm{N}$ was the extrapolation number. In addition, the $\mathrm{N}, \mathrm{D}_{0}, \mathrm{D}_{\mathrm{q}}$ (quasi-threshold dose) and SERwere calculated based on the dose-survival curve of $\mathrm{H}-520$ cells irradiated with ${ }^{60} \mathrm{Co} \gamma$ ray, SER is defined as following: SER $=\left(\mathrm{D}_{10}\right.$ of the group irradiated with ${ }^{60} \mathrm{Co} \gamma$ ray $) /\left(\mathrm{D}_{10}\right.$ of the group treated with combination of ${ }^{60} \mathrm{Co}$ and $\left.\mathrm{C} 225\right)$.

\section{Cell apoptosis determined by Hoechst33258-staining}

$\mathrm{H}-520$ cells were separated into three groups: control, C225-treated group and 8 Gy ${ }^{60} \mathrm{Co} \gamma$ ray irradiated group. After incubation for $72 \mathrm{~h}$, the cells were fixed and stained with $100 \mu \mathrm{g} / \mathrm{ml}$ Hoechst 33258 (Beijing Lanbosite Biotech. Co. Beijing, China) for $30 \mathrm{~min}$. Cells morphology were detected under fluorescence microscopy.

Cell cycle and apoptosis analysis by flow cytometry (FCM) Cells from the control and C225 groups were exposed to different dose of irradiation (0, 2, 4 and 8 Gy). Cells were harvested at $72 \mathrm{~h}$ after irradiation for cell apoptosis analyses by FCM. Cells for cycle analysis ( 0 and 8 Gy) were harvested at $48 \mathrm{~h}$ after irradiation. Each test was performed 3 times. Cells used for cell-cycle tests were stained with propidium iodide. Cells used for apoptosis tests were stained with propidium iodide (PI) and annexin V-FITC and analyzed by fluorescence-activated cell sorting (FACS) using Coulter EPICS and ModFit software (Verity Software House, Topsham, MN).

\section{The expression levels of Caspase-3 after treatment with C225 or/and irradiation}

Four groups were involved in this study: control group, C225 group (final concentration of $40 \mathrm{nM}$ ), irradiation group (8 Gy) and combination group (C225 of $40 \mathrm{nM}$ combined with irradiation of $8 \mathrm{~Gy}$ ). Cells were collected as before and $0.5 \mu \mathrm{L}$ Caspase- 3 specific antibody were added to each tube, and incubated for $15 \mathrm{~min}$ away from light after mixing the cell suspension. Cell suspension were adjusted to $300 \mu \mathrm{l}$ with PBS, and analyzed with FACS.

\section{Statistical analysis}

GraphPad prism software 4.0 was adopted to produce dose-survival curve. The statistics was performed with SPSS11.5 version. Measurement data were presented as mean \pm standard deviation $(\mathrm{x} \pm S D)$. The difference between the means of two different groups was analyzed with t-test, while ANOVA was sued for comparing 4 groups of treatment. $\mathrm{p}<0.05$ was considered significant.

\section{Results}

\section{High expression of EGFR in $\mathrm{H}-520$ cells}

In order to determine the expression of EGFR in our cell line H520, we firstly performed indirect staining to detect EGFR expression with FACS. The percentage of 
EGFR expression in normal lung tissue cells is below $10 \%$. However, as shown in Figure 1, 82\% of the H-520 cells expressed EGFR.

\section{Effects of C225 on H-520 cell growth}

From our previous study, we found the $40 \mathrm{nM} \mathrm{C} 225$ treatment showed approximately $50 \%$ inhibition of $\mathrm{H}$ 520 cell growth. We thus used $40 \mathrm{nM} \mathrm{C} 225$ for further analysis. We incubated H-520 cells with $40 \mathrm{nM} \mathrm{C} 225$ for different time points, and found that the growth inhibition rate was about $50 \% 72$ hours after $40 \mathrm{nM}$ C225 treatment. Prolonged treatment did not lead to higher growth inhibition, as shown in Figure 2.

\section{Enhanced radiosensitivity in EGFR inhibitor C225-treated H-520 cells}

The radiobiological parameters of C225-treated H-520 cells were $\mathrm{D}_{0}=1.32 \mathrm{~Gy}, \mathrm{Dq}=0.19 \mathrm{~Gy}, \mathrm{~N}=1.352$, while those of $\mathrm{C} 225$-untreated $\mathrm{H}-520$ cells were $\mathrm{D}_{0}=$ $1.82 \mathrm{~Gy}, \mathrm{Dq}=0.51 \mathrm{~Gy}, \mathrm{~N}=1.81$. In the present study, the SER was about 1.35 , which indicated that treatment with C225 significantly improved the biological effect of irradiation. The results were shown in Figure 3.

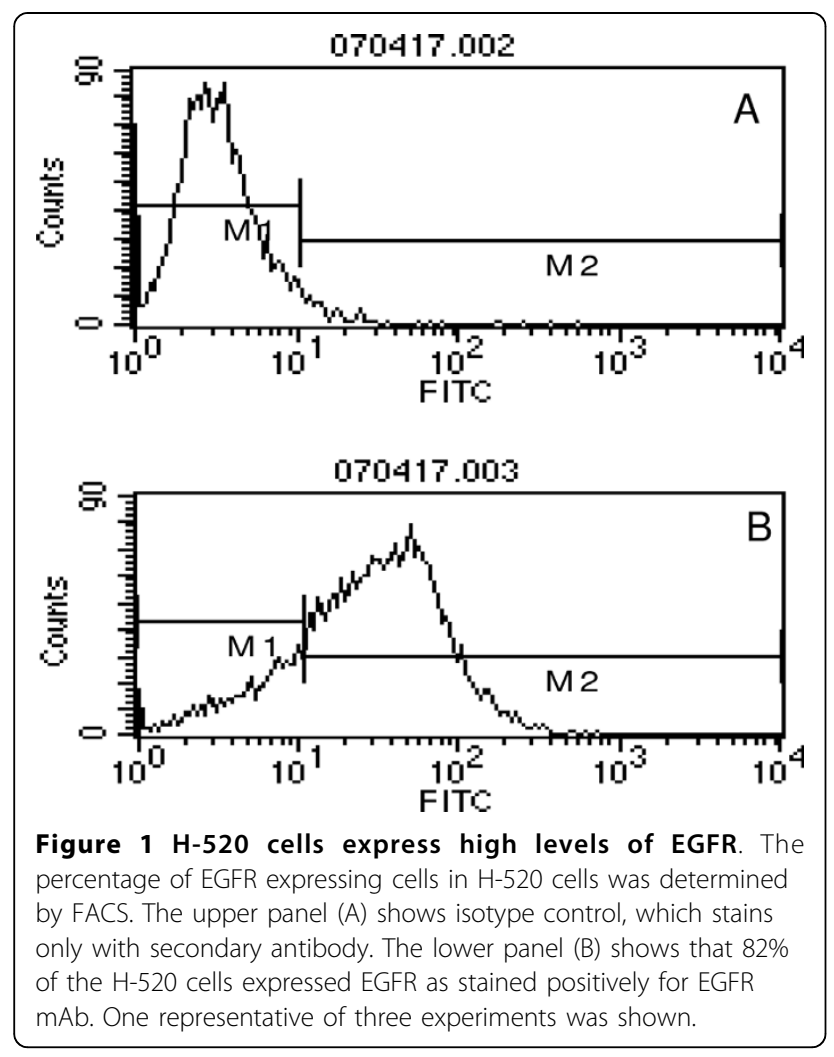

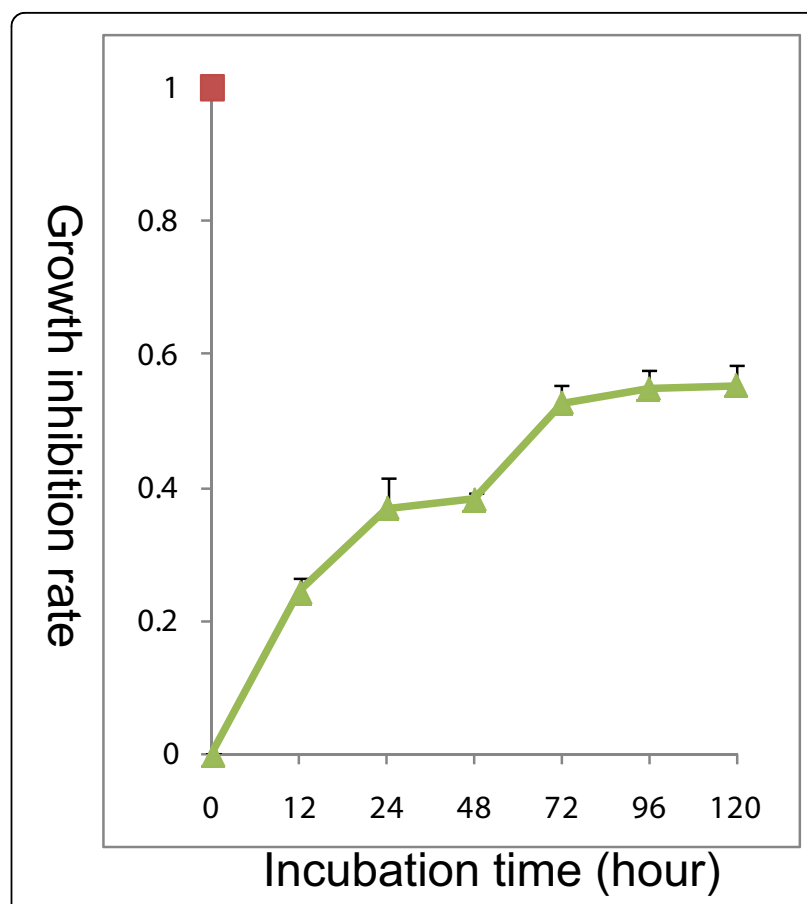

Figure 2 Growth inhibitory effects of C225 on human nonsmall cell lung cancer cells. Using MTT assay, we incubated H-520 cells with $40 \mathrm{nM} \mathrm{C225}$ for different time points, and found that the growth inhibition rate was about 50\% 72 hours after 40 nM C225 treatment. Further treatment did not cause higher growth inhibition. One representative of two experiments was shown.

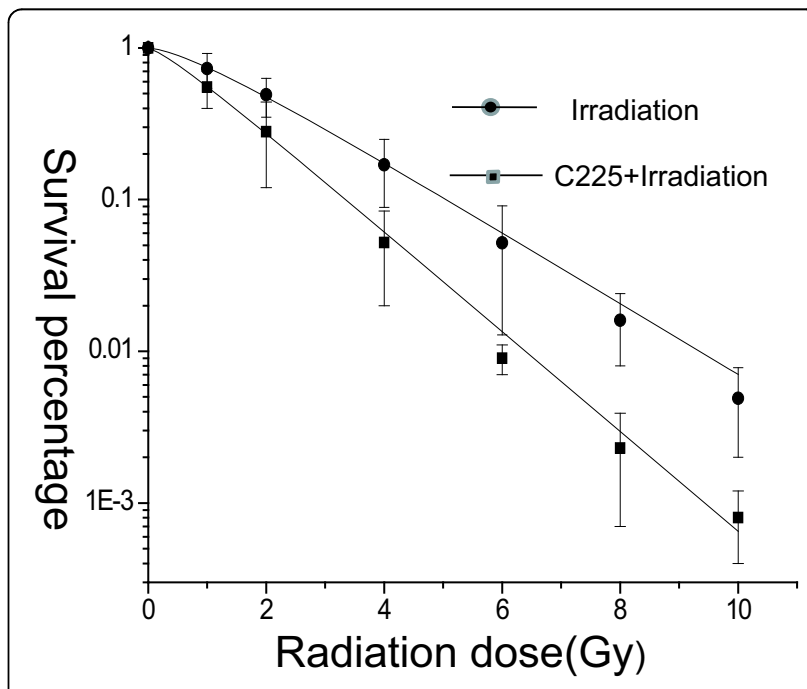

Figure 3 Radiosensitivity was enhanced by EGFR inhibitor C225. SER calculation was carried out and we found that treatment with C225 significantly improved the biological effect of irradiation. The radiobiological parameters of $\mathrm{C} 225$-treated $\mathrm{H}-520$ cells were $\mathrm{D}_{0}$ $=1.32, \mathrm{Dq}=0.19, \mathrm{~N}=1.352$, while those of irradiated $\mathrm{H}-520$ cells were $\mathrm{D}_{0}=1.82, \mathrm{Dq}=0.51, \mathrm{~N}=1.81$. Data were shown as Mean + $\mathrm{SD}(\mathrm{N}=4)$. One representative of three experiments with identical results was shown. 
Significantly enhanced cell apoptosis in C225-treated H$\mathbf{5 2 0}$ cells after irradiation

Under fluorescent microscope, it appeared apparently that, compared with irradiation group, C225 treatment together with irradiation significantly induced morphological changes of H-520 cells, including the majority of cells' nuclei was wavy (rippled), cell membrane folded, chromatin condensed, some of which were cracking as the fragments of the nucleus, resulting in the appearance of apoptotic bodies (data not shown).

The percentage of apoptosis cells was determined by flow cytometry. The apoptosis rate of $\mathrm{H}-520$ cells under conventional culture conditions was about $5 \%$, however C225 rose the percentage of cell apoptosis to $13.91 \pm$ $1.88(\mathrm{t}=3.59, \mathrm{P}<0.05$, Figure 4$)$. The apoptosis percentage of control group irradiated with 2 , 4, or 8 Gy $\gamma$ ray respectively was $13.88 \pm 2.38,24.67 \pm 1.77,30.36 \pm 2.81$, after treated with $\mathrm{C} 225$ coupled with irradiation the apoptosis percentage was $23.33 \pm 3.18(\mathrm{t}=2.16, \mathrm{P}<$ $0.05), 39.01 \pm 0.173(\mathrm{t}=4.74, \mathrm{P}<0.05)$, and $42.46 \pm$ $4.06(\mathrm{t}=5.65, \mathrm{P}<0.05)$, respectively. There was significant difference between $\mathrm{C} 225$ and irradiation combination group and irradiation group. The results were summarized in Table 1.

C225 arrested the cell cycle of $\mathrm{H}-520$ cells at $\mathrm{G}_{0} / \mathrm{G}_{1}$ phase As shown in Figure 5, C225 arrested the cell cycle of $\mathrm{H}$ 520 at $G_{0} / G_{1}$ phase from $43.64 \pm 1.54 \%$ to $52.55 \pm$ $2.67 \%$ determined by flow cytometry. Meanwhile, $\gamma$ ray irradiation arrested the cell cycle at $\mathrm{G}_{2} / \mathrm{M}$ phase from $10.83 \pm 1.52 \%$ to $29.95 \pm 2.6 \%$; when $\mathrm{C} 225$ coupled with irradiation the cell cycle arrested at both $G_{0} / G_{1}$ and $G_{2} /$ $\mathrm{M}$ phase, meanwhile the proportion of $\mathrm{S}$ phase reduced from $45.46 \pm 0.06 \%$ to $21.12 \pm 6.84 \%$.

\section{C225 increased the ratio of caspase- 3 in H520 cells}

The percentage of caspase-3-positive cells in control group, C225 group, irradiated group and C225 coupled with irradiation group was $7.8 \pm 0.94,54.1 \pm 7.56,17.7$ \pm 2.1 , and $66.9 \pm 10.4$, respectively. C225 increased the ratio of caspase- 3 positive cells significantly $(\mathrm{p}<0.05)$. The results were shown in Figure 6.

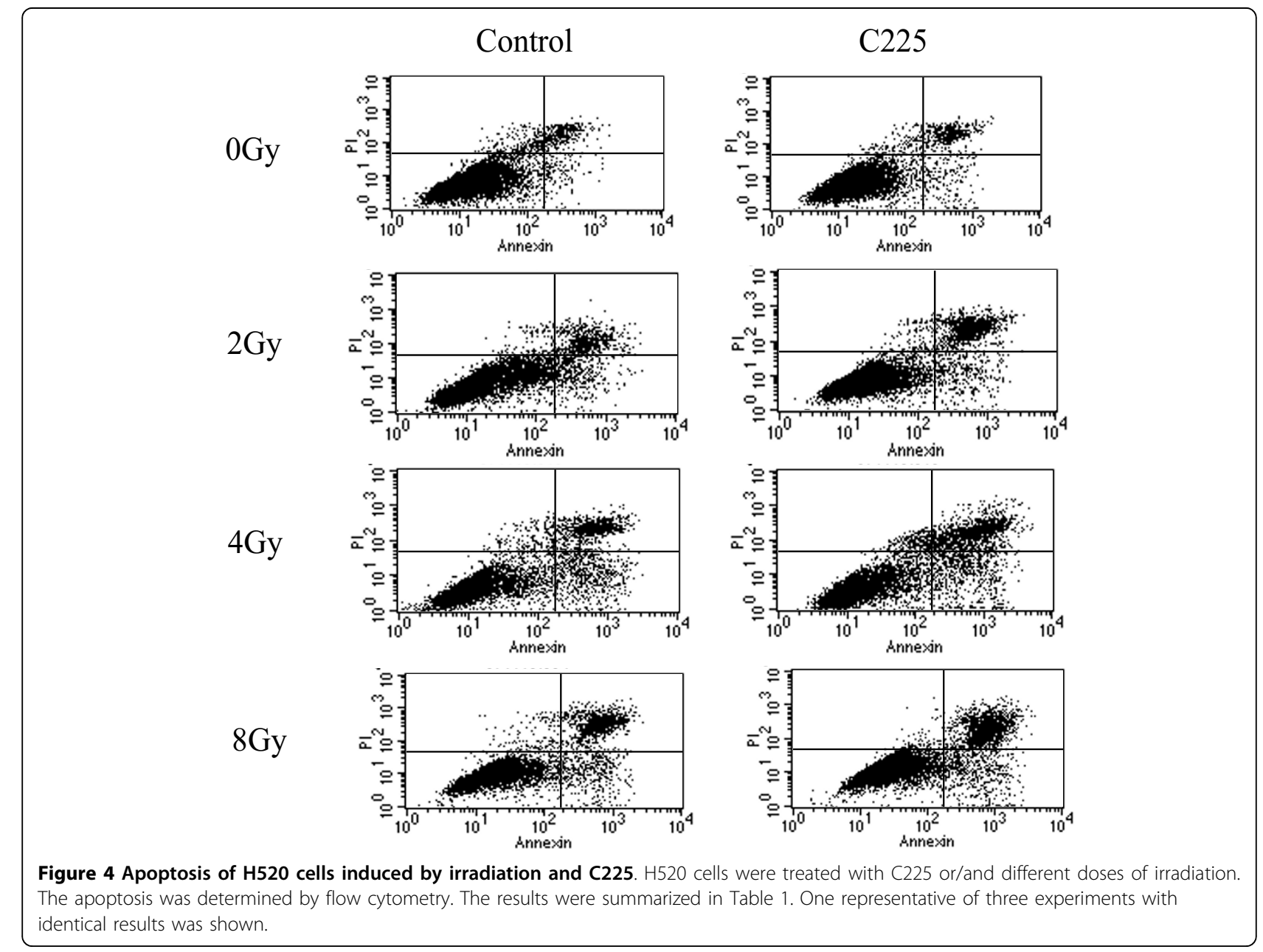


Table 1 H-520 cells apoptosis rate

\begin{tabular}{lllll}
\hline & \multicolumn{4}{l}{ Apoptosis rate $(\%, \times \pm$ SD) } \\
Groups & 0Gy & 2Gy & 4Gy & 8Gy \\
\hline Control & $5.75 \pm 0.64$ & $13.88 \pm 2.38$ & $24.67 \pm 1.77$ & $30.36 \pm 2.81$ \\
C225 & $13.91 \pm 1.88^{\mathrm{a}}$ & $23.33 \pm 3.18^{\mathrm{b}}$ & $39.01 \pm 0.73^{\mathrm{c}}$ & $42.46 \pm 4.06^{\mathrm{d}}$ \\
\hline
\end{tabular}

Note: $T$ test for the apoptosis rate of two groups at the same dose, ${ }^{\mathrm{a}} P=0.02 ;{ }^{\mathrm{b}} P=0.02 ;{ }^{\mathrm{c}} P=0.03 ;{ }^{\mathrm{d}} P=0.04$.

\section{Discussion}

The incidence and mortality of lung cancer are high and Lung cancer is the leading cause of cancer-related deaths [19]. Clinical diagnosis of $80-87 \%$ of patients with lung cancer is non-small cell lung cancer. Currently, radiotherapy and chemotherapy combined treatment for locally advanced NSCLC is the standard treatment program. One of the characteristics of chemotherapy is based on two kinds of platinum-based drugs in combination with radiation therapy to sequential or simultaneous delivery methods [20]. Though the new chemotherapy drugs and new drug combination has been introduced into the program, conventional radiotherapy has been substituted by three-dimensional stereotactic radiotherapy. Statistics show that over the past two decades, the survival time of patients with NSCLC remains no change. We found that the clinical treatment of the same stages and even the same type of patients using the same treatment, the patient's prognosis are different, it prompt us to speculate that the tumor pathological type may have a great impact on therapy options and prognosis of patients. In recent years, bio-molecular targeting therapy increasingly receives attention. In non-Hodgkin's lymphoma, renal cell cancer, colorectal cancer, non-small cell lung cancer and head and neck squamous cells cancer treatment, bio-targeting drugs have made a good effect [18,21].

Clinically, anti-EGFR monoclonal antibody C225 combined with radiotherapy showed a significant effect on head and neck squamous cell carcinoma, the C225 combined with radiotherapy as the conventional treatment options on head and neck squamous cell carcinoma have been acceptable to the majority of doctors [21,22]. Many biological characteristics of advanced NSCLC are consistent with the head and neck cancer. Squamous cell carcinoma is the majority of NSCLC, so in this experiment we use $\mathrm{H}-520$ cells as research materials to observe the effects of $\mathrm{C} 225$ and ${ }^{60} \mathrm{Co} \gamma$ treatment (alone/coupled) on the proliferation, apoptosis and changes in the cell cycle.

In the present study, we used H-520 cells as human non-small cell lung cancer cells. Though it is reported that H-520 cells do not express EGFR[20,23], we detected high level expression of EGFR as determined by flow cytometry. The inconsistency between our results and the published data may be due to the long term cell

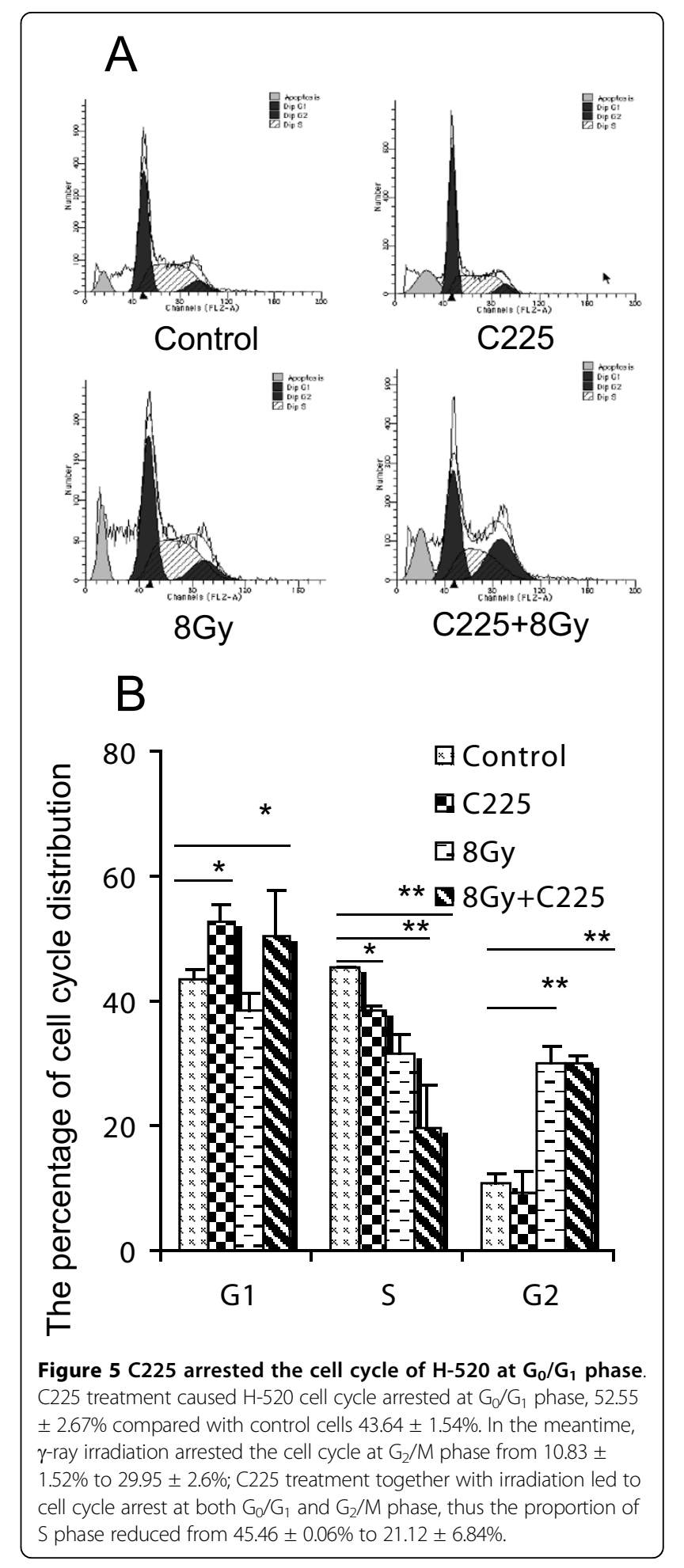

culture, the selected clone expansion and the other reasons in our labs, which should be determined in the future. The expression of EGFR may make our H-520 cells more sensitive to $\mathrm{C} 225$ treatment so that we can study the co-effect of radiation of $\mathrm{C} 225$ in this cell line. 


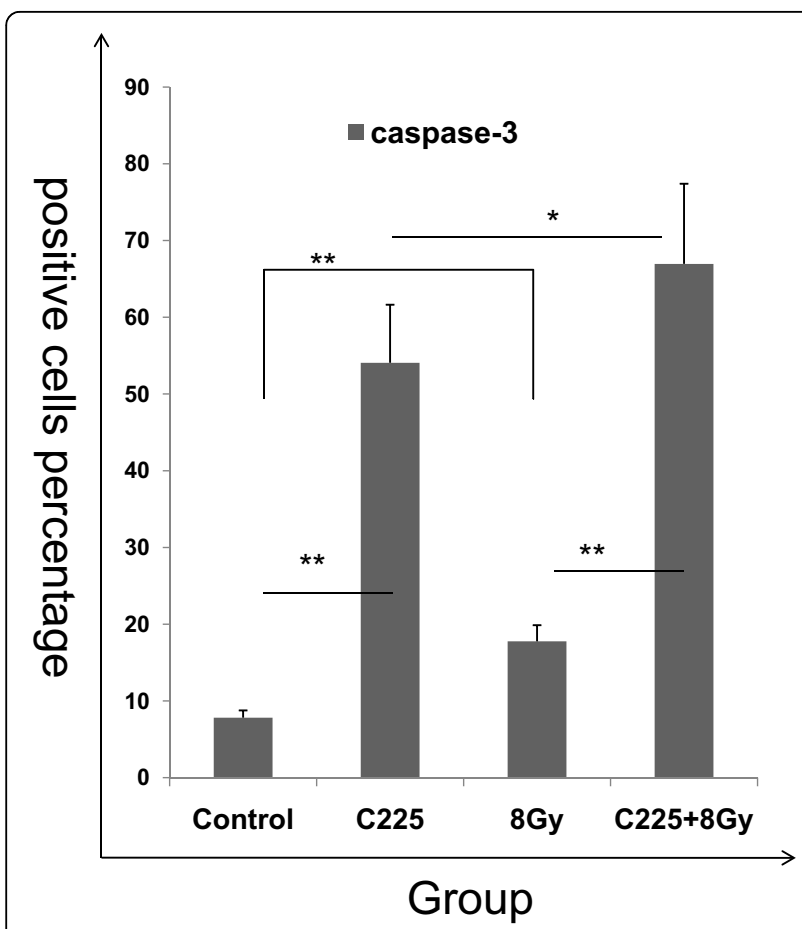

Figure 6 C225 increased the ratio of caspase-3 positive cells. C225 can significantly increase the percentage of caspase-3 positive cells $(p<0.05)$. The percentage of caspase-3-positive cells in control group, C225 group, irradiated group and C225 coupled with irradiation group was $7.8 \pm 0.94,54.1 \pm 7.56,17.7 \pm 2.1,66.9 \pm 10.4$, respectively. ${ }^{*} p<$ $0.05,{ }^{* *} p<0.01$ compared with the indicated groups.

Colony forming efficiency analysis is a classical method to evaluate the anti-tumor ability of $\gamma$ ray irradiation. Through analysis of cell survival curves we found that the $\mathrm{N}$ value of $\mathrm{C} 225$ combined with radiotherapy is smaller, the curves had no apparent shoulder area, which indicate that the $\mathrm{C} 225$ increased the sensitivity of the $\mathrm{H}-520$ cells to ${ }^{60} \mathrm{Co} \gamma$ ray irradiation. At the same time, the $D_{0}$ Value is relatively lower suggesting that the reasonable lower doses of ${ }^{60} \mathrm{Co} \gamma$ ray can also kill tumor cells when coupled with C225. The SER of C225 treatment is about 1.4 which suggested that C225 had radiosensitization effect on the $\mathrm{H}-520$ cells. It has been studied that after irradiation the expression of EGFR and TGF- $\alpha$ increased which enhanced the ability of the tumor cells to repair DNA damage, and rapidly proliferate $[24,25]$. The $\mathrm{C} 225$ which can combine with EGFR not only blocked the secretion of TGF- $\alpha$ and signal transduction but also decreased the expression of EGFR on the cell membrane surface [16]. These impeded the cell survival and proliferation.

The cell-cycle phase is one of the determinative factors of cell radiosensitivity [26]. In the present study we observed C225 arrested the cell cycle at the G0/G1 phase, ${ }^{60} \mathrm{Co} \gamma$ ray irradiation resulted in $\mathrm{G}_{2} / \mathrm{M}$ phase arrest, C225 in combination with ${ }^{60} \mathrm{Co} \gamma$ ray irradiation at the same time led to the cell cycle arrested at $G_{0} / G_{1}$, $\mathrm{G}_{2} / \mathrm{M}$ phase. Under normal condition, cell cycle arrests at some point in order to repair damage, when the damage repairs successfully, cell cycle continues, otherwise cells undergo apoptosis. It needs the participation of many growth factors to repair the irradiation induced damage for the cells arrested at $\mathrm{G}_{2} / \mathrm{M}$ phase [27]. When the EGFR pathway is blocked by $\mathrm{C} 225$, the repair is difficult to proceed smoothly, the cells will undergo apoptosis. With this match, C225 in combination with irradiation significantly increased the rate of apoptosis.

Caspase-3 plays an important role in the apoptosis process which hydrolytic DNA led cells to apoptosis, caspase-3 positive cells will be apoptotic eventually [28]. We found that $\mathrm{C} 225$ increased the number of caspase-3-positive cells significantly, the mechanism may be that $\mathrm{C} 225$ against with EGFR blocked the PI3K pathway which reduced Akt phosphorylation (Akt is an important protein molecule in PI3K pathway, it regulates caspase-9, GSK- $3 \beta, N F-\kappa B$, such as protein phosphorylation and ultimately controls cell survival and apoptosis) and then activated caspase- 9 and process of apoptosis using caspase-3 to cut DNA to complete the task of apoptosis.

In summary, C225, which blocks EGFR pathway, inhibited H520 lung squamous carcinoma cell proliferation, and increased the sensitivity of lung squamous cancer cells to irradiation dramatically.

\section{Acknowledgements}

The authors wish to thank Dr. Ageel Javeed and Dr. Dong-Mei Tian for critical reading of the manuscript, Ms. Jing Wang and Ms. Jian-Xia Peng for their expert technical assistance and Ms. Qing-Huan Li for her excellent laboratory management. This work was supported by a grant from the Ministry of Civil Affair, China ([2007] 18).

\section{Author details}

'Department of Radiation Oncology, Cancer center, Peking University Third Hospital, Beijing, P.R. China 100191. 'Transplantation Biology Research Division, State Key Laboratory of Biomembrane and Membrane Biotechnology, Institute of Zoology, Chinese Academy of Sciences, Beijing, P. R. China 100101 .

\section{Authors' contributions}

YDZ carried out cell colony-forming assay, fluorescence- activated cell sorting, flow cytometric analysis, and drafted the manuscript. JJW participated in its design and revised the manuscript. FL performed the statistical analysis. ZYY carried out the irradiation experiment. RJY revised the manuscript critically for important intellectual content and helped to draft the manuscript. $Y Z$ supervised experimental work and revised the manuscript. All authors read and approved the final manuscript.

\section{Competing interests}

The authors declare that they have no competing interests.

Received: 24 March 2009 Accepted: 23 October 2010

Published: 23 October 2010

\section{References}

1. Ray M, Salgia R, Vokes EE: The role of EGFR inhibition in the treatment of non-small cell lung cancer. Oncologist 2009, 14:1116-1130. 
2. Rosell R, Moran T, Carcereny E, Quiroga V, Molina MA, Costa C, Benlloch S Taron M: Non-small-cell lung cancer harbouring mutations in the EGFR kinase domain. Clin Transl Oncol 2010, 12:75-80.

3. Paz-Ares L, Soulieres D, Melezinek I, Moecks J, Keil L, Mok T, Rosell R, Klughammer B: Clinical outcomes in non-small-cell lung cancer patients with EGFR mutations: pooled analysis. J Cell Mol Med 2010, 14:51-69.

4. Kawahara A, Yamamoto C, Nakashima K, Azuma K, Hattori S, Kashihara M, Aizawa H, Basaki Y, Kuwano M, Kage M, Mitsudomi T, Ono M: Molecular diagnosis of activating EGFR mutations in non-small cell lung cancer using mutation specific antibodies for immunohistochemical analysis. Clin Cancer Res 2010, 16(12):3163.

5. Dong J, Dai J, Shu Y, Pan S, Xu L, Chen W, Wang Y, Jin G, Ma H, Zhang M, $\mathrm{Hu} \mathrm{Z}$, Shen $\mathrm{H}$ : Polymorphisms in EGFR and VEGF contribute to non-small cell lung cancer survival in a Chinese Population. Carcinogenesis 2010, 31(6):1080-1086

6. Doebele RC, Oton AB, Peled N, Camidge DR, Bunn PA Jr: New strategies to overcome limitations of reversible EGFR tyrosine kinase inhibitor therapy in non-small cell lung cancer. Lung Cancer 2010, 69(1):1-12.

7. Chen CC, Chiu HH, Yen LC, Chang HJ, Chang MS, Tsai JR, Chen YF, Lin SR: Overexpression of EGFR pathway-related genes in the circulation is highly correlated with EGFR mutations and overexpression in paired cancer tissue from patients with non-small cell lung cancer. Oncol Rep 2010, 23:639-645.

8. Baumann $M$, Krause $M$ : Targeting the epidermal growth factor receptor in radiotherapy: radiobiological mechanisms, preclinical and clinical results. Radiother Oncol 2004, 72:257-266.

9. Janmaat ML, Kruyt FA, Rodriguez JA, Giaccone G: Response to epidermal growth factor receptor inhibitors in non-small cell lung cancer cells: limited antiproliferative effects and absence of apoptosis associated with persistent activity of extracellular signal-regulated kinase or Akt kinase pathways. Clin Cancer Res 2003, 9:2316-2326.

10. Bonner JA, Harari PM, Giralt J, Azarnia N, Shin DM, Cohen RB, Jones CU, Sur R, Raben D, Jassem J, Ove R, Kies MS, Baselga J, Youssoufian H, Amellal N, Rowinsky EK, Ang KK: Radiotherapy plus cetuximab for squamous-cell carcinoma of the head and neck. N Engl J Med 2006, 354:567-578.

11. Zhang J, Ji J, Yuan F, Ma T, Ye ZB, Yu YY, Liu BY, Zhu ZG: [EGFR-blockade by antibody Cetuximab inhibits the growth of human gastric cancer xenograft in nude mice and its possible mechanism]. Zhonghua Zhong Liu Za Zhi 2009, 31:85-89.

12. Kies MS, Harari PM: Cetuximab (Imclone/Merck/Bristol-Myers Squibb). Curr Opin Investig Drugs 2002, 3:1092-1100

13. Bernier J, Schneider D: Cetuximab combined with radiotherapy: an alternative to chemoradiotherapy for patients with locally advanced squamous cell carcinomas of the head and neck? Eur J Cancer 2007, 43:35-45.

14. Kim ES, Vokes EE, Kies MS: Cetuximab in cancers of the lung and head \& neck. Semin Oncol 2004, 31:61-67.

15. Bernier J: Cetuximab in the treatment of head and neck cancer. Expert Rev Anticancer Ther 2006, 6:1539-1552

16. Liao HJ, Carpenter G: Cetuximab/C225-induced intracellular trafficking of epidermal growth factor receptor. Cancer Res 2009, 69:6179-6183.

17. Le Tourneau C, Siu LL: Molecular-targeted therapies in the treatment of squamous cell carcinomas of the head and neck. Curr Opin Oncol 2008 20:256-263.

18. Bonner JA, De Los Santos J, Waksal HW, Needle MN, Trummel HO, Raisch KP: Epidermal growth factor receptor as a therapeutic target in head and neck cancer. Semin Radiat Oncol 2002, 12:11-20.

19. Dy GK, Adjei AA: Novel targets for lung cancer therapy: part I. J Clin Oncol 2002, 20:2881-2894.

20. Raben D, Helfrich B, Chan DC, Ciardiello F, Zhao L, Franklin W, Baron AE, Zeng C, Johnson TK, Bunn PA Jr: The effects of cetuximab alone and in combination with radiation and/or chemotherapy in lung cancer. Clin Cancer Res 2005, 11:795-805.

21. Harari PM, Huang SM: Head and neck cancer as a clinical model for molecular targeting of therapy: combining EGFR blockade with radiation. Int J Radiat Oncol Biol Phys 2001, 49:427-433.

22. Early success of combined EGFR and Her2 receptor blockade as a clinical strategy in breast cancer. Cancer Biol Ther 2004, 3:490

23. Weiss GJ, Bemis LT, Nakajima E, Sugita M, Birks DK, Robinson WA, VarellaGarcia M, Bunn PA Jr, Haney J, Helfrich BA, Kato H, Hirsch FR, Franklin WA:
EGFR regulation by microRNA in lung cancer: correlation with clinica response and survival to gefitinib and EGFR expression in cell lines. Ann Oncol 2008, 19:1053-1059.

24. Dent P, Reardon DB, Park JS, Bowers G, Logsdon C, Valerie K, SchmidtUllrich R: Radiation-induced release of transforming growth factor alpha activates the epidermal growth factor receptor and mitogen-activated protein kinase pathway in carcinoma cells, leading to increased proliferation and protection from radiation-induced cell death. Molecular biology of the cell 1999, 10:2493-2506.

25. Hagan M, Yacoub A, Dent P: Ionizing radiation causes a dose-dependent release of transforming growth factor alpha in vitro from irradiated xenografts and during palliative treatment of hormone-refractory prostate carcinoma. Clin Cancer Res 2004, 10:5724-5731.

26. Geldof AA, Plaizier MA, Duivenvoorden I, Ringelberg M, Versteegh RT, Newling DW, Teule GJ: Cell cycle perturbations and radiosensitization effects in a human prostate cancer cell line. J Cancer Res Clin Oncol 2003, 129:175-182

27. Fan OW, Weiss WA: RNA interference against a glioma-derived allele of EGFR induces blockade at G2M. Oncogene 2005, 24:829-837.

28. Sohn EJ, Li H, Reidy K, Beers LF, Christensen BL, Lee SB: EWS/FLI1 oncogene activates caspase 3 transcription and triggers apoptosis in vivo. Cancer Res 2010, 70:1154-1163.

doi:10.1186/1475-2867-10-39

Cite this article as: Zhang et al:: EGFR inhibitor C225 increases the radiosensitivity of human lung squamous cancer cells. Cancer Cell International 2010 10:39.

\section{Submit your next manuscript to BioMed Central and take full advantage of:}

- Convenient online submission

- Thorough peer review

- No space constraints or color figure charges

- Immediate publication on acceptance

- Inclusion in PubMed, CAS, Scopus and Google Scholar

- Research which is freely available for redistribution
Biomed Central 